\section{Commentary: Valve-sparing surgery: The devil is in the details}

\author{
Hans-Joachim Schäfers, MD
}

Aortic root aneurysm in patients with Marfan syndrome was the major cause of death before the days of prophylactic surgery. The prognosis was improved drastically with the introduction of composite replacement of valve and root. Such an operation, however, exposes the patients to the lifelong risks of thromboembolism and hemorrhage, which can create additional problems if further aortic surgery is needed. Thus, the treatment of root aneurysm in this patient population was apparently revolutionized by the introduction of valve-preserving surgery (VPS), namely valve reimplantation. ${ }^{1}$ Excellent results were published by single centers, with good stability and low incidence of valverelated complications. The results, however, were not always good, with an increased probability of valve failure than in the pioneering series. ${ }^{1,2}$ To clarify the true role of VPS, a prospective study was planned and initiated, hoping to generate objective information.

The 5-year results of that multicenter trial are now available. ${ }^{3}$ Patients were enrolled from 19 sites, and care was taken to control many genetic and medical aspects of the patients. The statistical analysis was very elaborate. Surprisingly, the authors found twice as many valve-related events at 5 years in the VPS group compared with composite replacement, ${ }^{3}$ with new occurrence of aortic incompetence $\geq$ II being the most frequent event. These results appear sobering compared with the previous single-center results. Thus, the reader can come to the conclusion that VPS is not as good as believed, and its use should be reconsidered. One has to be careful, however, with the interpretation of the findings. Even though almost every detail was

From the Department of Thoracic and Cardiovascular Surgery, Saarland University Medical Center, Homburg/Saar, Germany.

Disclosures: The author reported no conflicts of interest.

The Journal policy requires editors and reviewers to disclose conflicts of interest and to decline handling or reviewing manuscripts for which they may have a conflict of interest. The editors and reviewers of this article have no conflicts of interest

Received for publication Aug 30, 2021; revisions received Aug 30, 2021; accepted for publication Aug 31, 2021; available ahead of print Sept 8, 2021.

Address for reprints: Hans-Joachim Schäfers, MD, Department of Thoracic and Cardiovascular Surgery, Saarland University Medical Center, Kirrbergerstr 100, 66421 Homburg/Saar, Germany (E-mail: H-J.Schaefers@uks.eu).

J Thorac Cardiovasc Surg 2023;165:1800-1

0022-5223/\$36.00

Copyright (c) 2021 by The American Association for Thoracic Surgery

https://doi.org/10.1016/j.jtcvs.2021.08.080

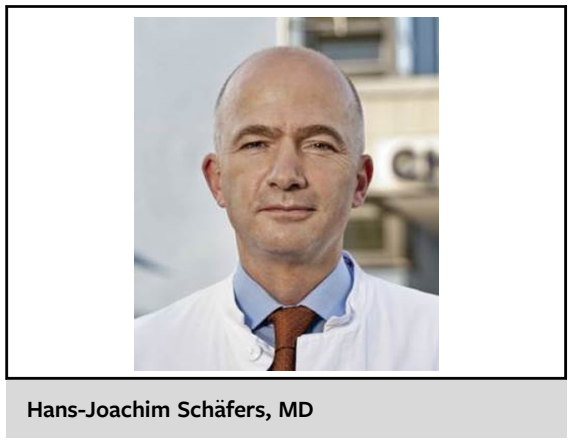

CENTRAL MESSAGE

The results of valve-sparing surgery depend on a number of pre- and intraoperative factors. An analysis without consideration of these factors may distort results and conclusion.

controlled in the study, the operation itself was not well standardized, as the authors state themselves.

VPS differs markedly from valve or composite replacement, which is performed in standard fashion and yields reproducible results. In VPS, however, the functional results depend on how precisely a normal or near-normal form of the aortic valve is generated. This in turn depends on preoperative and intraoperative details. Beyond the "normal" appearance of the cusps, the size of the cusps ${ }^{4}$ the presence of fenestrations or preexistent prolapse, or seemingly less important details like muscle extension into the sinuses may have an effect on the result. ${ }^{5}$ Operative factors include the level of root dissection, the height and circumferential location of the commissures, and the control of valve form; visual inspection has shown to yield much poorer functional results than the measurement of effective height. ${ }^{6}$ All details must be standardized or controlled if the true clinical result of VPS is to be judged. To what degree such control was part of the investigation is unclear. The authors themselves state that the operations were not well standardized.

Thus, the current results do not imply that VPS is an inferior composite replacement; they should rather stimulate research into detailed reasons for the results. In addition, surgeons should be encouraged to better control the details of operations that are as complex as VPS to improve it further. 


\section{References}

1. David TE, Feindel CM. An aortic valve-sparing operation for patients with aortic incompetence and aneurysm of the ascending aorta. J Thorac Cardiovasc Surg. 1992;103:617-21; discussion 622

2. Arabkhani B, Mookhoek A, Di Centa I, Lansac E, Bekkers JA, De Lind Van Wijngaarden R, et al. Reported outcome after valve-sparing aortic root replacement for aortic root aneurysm: a systematic review and meta-analysis. Ann Thorac Surg. 2015;100:1126-31

3. Coselli JS, Volguina IV, LeMaire SA, Connolly HM, Sundt TM, Milewicz DM, et al. Midterm outcomes of aortic root surgery in patients with Marfan syndrome: a prospective, multicenter, comparative study. J Thorac Cardiovasc Surg. 2023; 165:1790-9.

4. Schäfers HJ, Schmied W, Marom G, Aicher D. Cusp height in aortic valves. J Thorac Cardiovasc Surg. 2013;146:269-74.

5. Matsushima S, Karliova I, Gauer S, Miyahara S, Schäfers HJ. Geometry of cusp and root determines aortic valve function. Indian J Thorac Cardiovasc Surg. 2020;36(suppl 1):64-70

6. Lansac E, Di Centa I, Sleilaty G, Lejeune S, Berrebi A, Zacek P, et al. Remodeling root repair with an external aortic ring annuloplasty. J Thorac Cardiovasc Surg. 2017;153:1033-42.
See Article page 1790.

\section{Commentary: Time to reassess valve reimplantation for root aneurysms in Marfan syndrome?}

\author{
Lars G. Svensson, MD, PhD
}

The paper by Coselli and colleagues ${ }^{1}$ on the role of aortic valve reimplantation (AVI) versus aortic valve replacement (AVR) for root aneurysms from a multicenter study on Marfan syndrome (MFS) is an important report that raises several questions:

1. Should reimplantation be used for patients with connective tissue disorders (CTD)?

2. Should all surgeons be expected to demonstrate competency in performing reimplantations?

3. Is there a problem with the method or methods or the graft prosthesis being used?

In summary, outcomes of AVI versus AVR done by 46 surgeons (mean of 5.2, [2.39/46] operations per surgeon) were compared at a median of 64 months of follow-up, with propensity matching showing AVI was associated with greater valve failure rate versus AVR by echocardiography but not reintervention (2 AVR vs 6 AVI). In addition,

From the Heart, Vascular, and Thoracic Institute, Cleveland Clinic, Cleveland, Ohio. Disclosures: The author reported no conflicts of interest.

The Journal policy requires editors and reviewers to disclose conflicts of interest and to decline handling or reviewing manuscripts for which they may have a conflict of interest. The editors and reviewers of this article have no conflicts of interest.

Received for publication Sept 8, 2021; revisions received Sept 8, 2021; accepted for publication Sept 9, 2021; available ahead of print Sept 16, 2021.

Address for reprints: Lars G. Svensson, MD, PhD, Cleveland Clinic Department of Thoracic and Cardiovascular Surgery, 9500 Euclid Ave/J1-227, Cleveland, OH 44195 (E-mail: svenssl@ccf.org).

J Thorac Cardiovasc Surg 2023;165:1801-2

$0022-5223 / \$ 36.00$

Copyright (C) 2021 by The American Association for Thoracic Surgery

https://doi.org/10.1016/j.jtcvs.2021.09.017
Check for updates

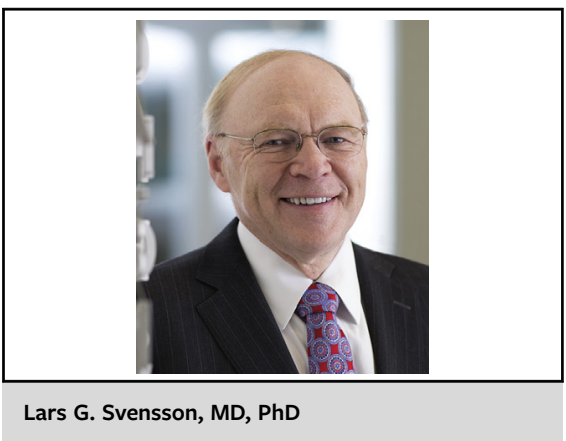

CENTRAL MESSAGE

Current study outcomes raise questions for further study about aortic valve reimplantation, surgeon proficiency, and graft type-specifically for patients with Marfan syndrome.

greater-volume centers had a lower mortality rate $(P=.04)$, as well as a lower valve-related morbidity and mortality rate $(P=.03)$. The authors tried to remove the competing risk effect of death and found similar results (see a discussion about this issue using conditional probability beyond this commentary). ${ }^{2}$ Of note, by implication from the paper, as the surgeons went through the learning curve of the AVI procedure, they became more comfortable performing the operation, decreasing from $35 \%$ AVR to $6 \%$ in the last year of study. Indeed, the results likely would have been better if patients were examined for outcomes once the surgeons had gone through the learning curve.

Similar to the results in our forthcoming report, which examined the results of 568 patients with AVI with longer follow-up, out of our total of 1191 patients with AVI, as of August 2021, preoperative regurgitation grade was found to be associated with a high failure rate. We also found that 